\title{
United States still angry
}

\section{Washington \& Parls}

IN an unusually frank report, the US State Department last week reiterated its decision not to rejoin the United Nations Educational, Scientific and Cultural Organization (UNESCO).

Since the United States pulled out of UNESCO in 1984, the organization has made little progress towards needed reforms, the report says. UNESCO remains badly managed, refuses to reduce its bloated bureaucracy, and continues actively to support the Palestinian Liberation Organization and programmes that could result in media censorship.

"Bluntly stated, UNESCO needs the United States as a member far more than the United States needs UNESCO", the report states. In declining to add an estimated $\$ 50$ million a year in dues to the $\$ 189$ million UNESCO annual budget, "the leverage we retain as a sought-after non-member in some instances is greater than we would wield simply by being 1 vote among 161 others". The State Department paid particular attention to UNESCO's performance in the two years since Federico Mayor of Spain took over as director-general from Amadou-Mahtar M'Bow of Senegal. Despite Mayor's promises of substantial reforms, the report says problems in the size and efficiency of UNESCO's bureaucracy and its lack of budgetary restraint have not been addressed. Both the budget and staff have continued to grow.

Mayor has a reputation as a "wellintentioned but poor administrator", the report says. In recent months, it claims, much of the UNESCO staff has openly rebelled against Mayor's attempts to restructure the bureaucracy. It quotes a memorandum from one UNESCO delegate who complains that "the wishes and intentions of the member states ... are either being misunderstood, ignored, side-tracked, or flouted". Although Mayor had previously promised to end the New World Information and Communication Order, a controversial initiative that sought to ensure "balance" in media reporting, he has continued to support the programme internally, the State Department asserts. The initiative is seen by the State Department as a device to censor the press, a concern that was raised again this year when Mayor selected a Soviet national to run UNESCO's newly created communications sector.

Mayor has also been unable to control the size of his staff or the use of contractors, the report claims. Last year, UNESCO employed 550 consultants, a number equal to nearly a quarter of its staff. And despite promising that he would cut staff by 700 people, Mayor has actually increased staff size, according to the State Department study. More than 70 per cent of UNESCO's budget is spent in its Paris headquarters, rather than in the field.

Interviewed in Washington last week, Mayor lashed out at the US report as "biased" and "politically motivated". The study ignores many of the positive changes in UNESCO such as its new literacy initiative, he said. Postponing US re-entry to UNESCO, he added, will "make the implementation of UNESCO's reform process more difficult".

$\mathrm{He}$ also contested the claim that the United States can exert more effective leverage from outside. Other UNESCO officials go further, saying they believe that the United States has already done all the damage it can do. They point out that many US observers, such as Representative Jim Leach (Republican, Iowa), believe that the United States could even be embarrassed by staying outside UNESCO. "It was nuts to get out and it is nuttier still not to rejoin", Leach said in a congressional statement last week.

Some UNESCO officials say that many of Mayor's difficulties have come from trying to satisfy US concerns. The recent staff work stoppage that the State Department report mentions was due to USendorsed austerity measures rather than clumsy management, says Yaw Turkson, a Mayor aide. Mayor "wants to change, but the staff said 'no'. So the [US] report comes back and says the staff is against him", he says.

Turkson says that the real victims of a continued US boycott are the developing countries. By withholding its funds to force UNESCO reforms, the United States is trading literacy in developing countries for its own diplomatic aims, he says. "Even if it's true that the United States has more clout out than in, how can they publicly say it? Have they no interest in the Third World?", he asks.

$\mathrm{He}$ also points out that the US report stands in marked contrast to a recent report from the UK House of Commons Select Committee on Foreign Affairs, chaired by Timothy Sainsbury (see Nature 344, 368; 1990). Although Sainsbury reaffirmed that Britain was still not ready to rejoin UNESCO, the UK report noted that improvements had been made within the organization and the situation should be appraised again in another year.

Mayor said he will ask the State Department for a further report. He did not specify when he would make the request, but he said that UNESCO would fully cooperate with US observers and information requests.

G. Christopher Anderson \& Peter Coles

\section{Gruinard Island handed back}

London

THE UK Ministry of Defence is handing back a remote Scottish island, nearly $\mathbf{5 0}$ years after it was requisitioned for wartime biological warfare experiments. On 1 May,

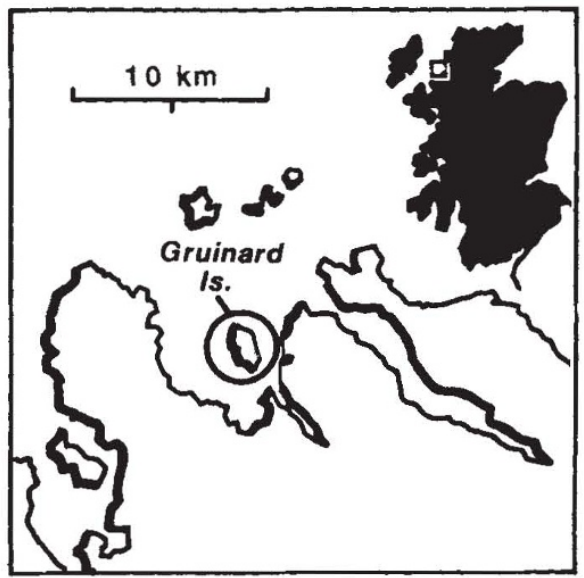

Gruinard Island, off the northwest coast of Scotland will be sold back to the heirs of its original owner, for $£ 500$ - equal to the compensation paid to the owner at the end of the Second World War.

Bombs containing anthrax (Bacillus anthracis) spores were detonated on the island in 1942 and 1943, as part of a British, Canadian and United States research programme set up in response to fears that the Germans were developing biological weapons. Anthrax was chosen because its resistant spores survive explosions, and are released as an aerosol causing fatal disease if inhaled by man or animals.

For most of the intervening period, the island has laid derelict, strictly off-limits to civilians, in the hope that traces of anthrax would eventually disappear. But in the early 1980 s, surveys showed that contamination was limited to the immediate area of the experiments. In 1986 and 1987, these areas were decontaminated by spraying with 5 per cent formaldehyde in sea water.

The island was passed as safe in $\mathbf{1 9 8 8}$, by a group of independent scientists led by Professor Bill Stewart, secretary of the Agricultural and Food Research Council, after a local farmer had grazed his flock of 40 sheep on the island for several months with no ill effects.

Peter Aldhous

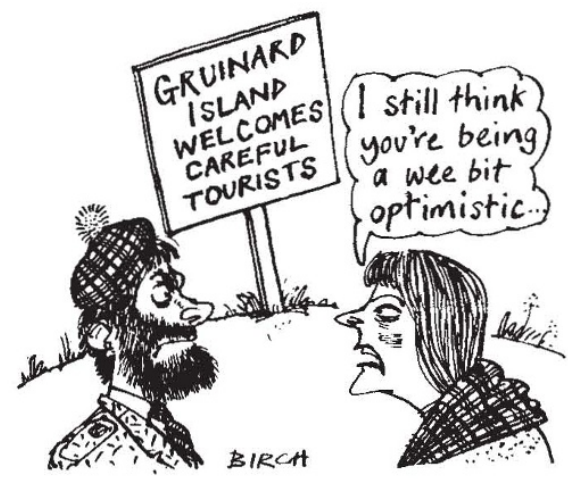

